\title{
Effects of Roselle Extract, Potato Peel Flour, and Beef Fat on the Formation of HCA of Beef Patties Studied by Response Surface Methodology ${ }^{\dagger}$
}

\author{
Anna Judith Pérez-Báez ${ }^{1}$, Martin Valenzuela-Melendres ${ }^{1, *}$, Juan Pedro Camou ${ }^{1}$, Gustavo González-Aguilar ${ }^{1}$ \\ and Manuel Viuda-Martos ${ }^{2}$ \\ 1 Centro de Investigación en Alimentación y Desarrollo, A.C. Carretera Gustavo E. Astiazarán Rosas, \\ \#46. Hermosillo, Sonora 83304, Mexico; anna.perez@estudiantes.ciad.mx (A.J.P.-B.); jpc@ciad.mx (J.P.C.); \\ gustavo@ciad.mx (G.G.-A.) \\ 2 Departamento de Tecnología Agroalimentaria, Escuela Politécnica Superior de Orihuela \\ (Universidad Miguel Hernández), Grupo de Industrialización de Productos de Origen Animal, \\ Carretera Beniel, km 3.2, E-Orihuela, 03312 Alicante, Spain; mviuda@umh.es \\ * Correspondence: martin@ciad.mx \\ † Presented at the 1st International Electronic Conference on Food Science and Functional Foods, \\ 10-25 November 2020; Available online: https://foods_2020.sciforum.net/.
}

Citation: Pérez-Báez, A.J.;

Valenzuela-Melendres, M.; Camou, J.P.; González-Aguilar, G.;

Viuda-Martos, M. Effects of Roselle Extract, Potato Peel Flour and Beef

Fat on the Formation of HCA of Beef Patties Studied by Response Surface Methodology. Proceedings 2021, 70, 27. https://doi.org/10.3390/ foods_2020-07656

Published: 9 November 2020

Publisher's Note: MDPI stays neutral with regard to jurisdictional claims in published maps and institutional affiliations.

Copyright: $@ 2020$ by the authors. Licensee MDPI, Basel, Switzerland. This article is an open access article distributed under the terms and conditions of the Creative Commons Attribution (CC BY) license (http://creativecommons.org/licenses/by/4.0/).

\begin{abstract}
Heterocyclic amines (HCA) are compounds formed by heating meat at a high temperature. Formation of HCA in meat products should be minimized by applying different approaches. The objective of this study was to investigate the effects of roselle extract (RE, $0 \%-1 \%$ ), potato peel flour (PP, $0 \%-2 \%)$, and beef fat (BF, $0 \%-15 \%$ ) on the formation of HCA in beef patties using response surface methodology. IQx, IQ, MeIQx, MeIQ, 4,8-DiMeIQx, and PhIP were identified and quantified by HPLC. Values from 0 to $18.09 \mathrm{ng}$ IQx, 0.20 to $11.66 \mathrm{ng} \mathrm{IQ}, 0.29$ to $3.93 \mathrm{ng}$ MeIQx, 0.19 to $11.51 \mathrm{ng}$ MeIQ, 0.65 to $1.72 \mathrm{ng}$ 4,8-DiMeIQx, and 1.87 to $14.7 \mathrm{ng}$ PhIP per gram of sample were obtained. All models were significant $(p<0.05)$, with no lack of fit $(p>0.05)$ and showed a determination coefficient $>0.70$. Roselle extract had a negative linear effect on the formation of the total HCA, while PP and BF had a positive quadratic effect. The optimal formula that minimizes the formation of HCA included $0.80 \%$ RE, $0.85 \%$ PP, and $7.54 \%$ BF. Roselle extract and potato peel are foods that can be used as ingredients to minimize the formation of HCA in beef patties.
\end{abstract}

Keywords: heterocyclic amines; functional meat products; roselle; potato peel; beef patties

\section{Introduction}

A higher incidence of cancer has been reported when the intake of fruits and vegetables is low [1], when the consumption of foods with an elevated glycemic index increases [2], or when the meat intake is high [3]. With respect to the latter one, genotoxic compounds, such as heterocyclic amines (HCA), may form during cooking at high temperatures from Millard reactions between creatine, free amino acids, and carbohydrates present in meat [4]. The HCA ingested through foods and, subsequently absorbed into the body, are converted in genotoxic metabolites. These metabolites react with the DNA of various tissues to form adducts that lead to cancer problems.

The increase of the risk of cancer due to ingestion of HCA from food is an important issue in which it is necessary to seek solutions, by reducing the formation of these compounds during meat preparation. The use of vegetable tissue or extracts, as an antioxidant source, is one of the best strategies for the reduction of HCA. This is because the polyphenolic compounds, present in some vegetables, inhibit the formation of free radicals, preventing HCA formation. The addition of calyx or roselle extract, to meat products, has 
been researched as a source of natural antioxidants. However, few articles have thoroughly studied their impact on HCA formation [5]. On the other hand, potato peel contains polyphenolic compounds, which, in aqueous extracts, have shown antioxidant activity [6]. Finally, beef fat is susceptible to oxidation, which is accelerated during cooking, producing free radicals that may be involved in the formation of HCA [7]. The objective of this research was to evaluate the effects of roselle extract, potato peel, and fat addition on the formation of HCA using response surface methodology.

\section{Materials and Method}

\subsection{Experimental Design}

The effects of roselle extract (RE, $0 \%-1 \%$ ), potato peel flour (PP, $0 \%-2 \%$ ), and beef fat (BF, $0 \%-15 \%$ ) addition on the formation of HCA (IQx, IQ, MeIQx, MeIQ, 4,8-DiMeIQx, $\mathrm{PhIP}$ ) in beef patties was determined using central composite design (CCD). The experimental design consisted of 20 treatments specified in Table 1.

Table 1. Coded and experimental values of the response variables for the central composite design (CCD).

\begin{tabular}{|c|c|c|c|c|c|c|c|}
\hline \multirow{2}{*}{ run. } & \multicolumn{3}{|c|}{ Coded Values } & \multicolumn{3}{|c|}{ Experimental Values * } & \multirow[b]{2}{*}{ Totals HCA ** } \\
\hline & $X_{1}$ & $X_{2}$ & $X_{3}$ & Roselle Extract & Potato Peel Flour & Fat & \\
\hline 1 & -1 & -1 & -1 & 0.20 & 0.40 & 3.04 & 36.8 \\
\hline 2 & 1 & -1 & -1 & 0.80 & 0.40 & 3.04 & 17.0 \\
\hline 3 & -1 & 1 & -1 & 0.20 & 1.60 & 3.04 & 51.8 \\
\hline 4 & -1 & -1 & 1 & 0.20 & 0.40 & 11.96 & 20.5 \\
\hline 5 & 1 & 1 & -1 & 0.80 & 1.60 & 3.04 & 36.4 \\
\hline 6 & 1 & -1 & 1 & 0.80 & 0.40 & 11.96 & 10.5 \\
\hline 7 & -1 & 1 & 1 & 0.20 & 1.60 & 11.96 & 45.7 \\
\hline 8 & 1 & 1 & 1 & 0.80 & 1.60 & 11.96 & 11.2 \\
\hline 9 & -1.68 & 0 & 0 & 0 & 1.00 & 7.50 & 32.8 \\
\hline 10 & 1.68 & 0 & 0 & 1.00 & 1.00 & 7.50 & 4.3 \\
\hline 11 & 0 & -1.68 & 0 & 0.50 & 0 & 7.50 & 26.9 \\
\hline 12 & 0 & 1.68 & 0 & 0.50 & 2.00 & 7.50 & 20.5 \\
\hline 13 & 0 & 0 & -1.68 & 0.50 & 1.00 & 0 & 21.1 \\
\hline 14 & 0 & 0 & 1.68 & 0.50 & 1.00 & 15.00 & 12.6 \\
\hline 15 & 0 & 0 & 0 & 0.50 & 1.00 & 7.50 & 15.8 \\
\hline 16 & 0 & 0 & 0 & 0.50 & 1.00 & 7.50 & 12.4 \\
\hline 17 & 0 & 0 & 0 & 0.50 & 1.00 & 7.50 & 7.9 \\
\hline 18 & 0 & 0 & 0 & 0.50 & 1.00 & 7.50 & 11.5 \\
\hline 19 & 0 & 0 & 0 & 0.50 & 1.00 & 7.50 & 9.7 \\
\hline 20 & 0 & 0 & 0 & 0.50 & 1.00 & 7.50 & 8.0 \\
\hline
\end{tabular}

$\mathrm{X}_{1}$ : roselle extract, $\mathrm{X}_{2}$ : potato peel flour, $\mathrm{X}_{3}$ : fat, ${ }^{*} \mathrm{~g} / 100 \mathrm{~g}$ of product, ${ }^{* *} \mathrm{ng} / \mathrm{g}$, run 1-8 are factorial points, $9-14$ are axial points, 15-20 are center points.

\subsection{Beef Patties Preparation}

All ingredients were mixed according to Table 1, and homogenized for $3 \mathrm{~min}$. In addition, $70 \mathrm{~g}$ of the resulting batter were manually shaped into beef patties. Each beef patty was cooked for $4 \mathrm{~min}$ per side at $190 \pm 10^{\circ} \mathrm{C}$.

\subsection{Extraction of Heterocyclic Amines}

The extraction of heterocyclic amines was according to Messner et al. [8] with slight modifications. One gram of lyophilized sample was homogenized in $12 \mathrm{~mL} 1 \mathrm{M} \mathrm{NaOH}$. The suspension was shaken for $1 \mathrm{~h}$ at $300 \mathrm{rpm}$ and at room temperature. Subsequently, 13 
g of diatomaceous earth (Extrelut NT, Merck, Darmstadt, Germany) was added, homogenized, and poured into a column of Extrelut NT20. Extraction was performed by washing the column with $75 \mathrm{~mL}$ of ethyl acetate, which was passed through an ion exchange (Waters, Milford, MA, USA) Oasis MCX cartridge $\left(3 \mathrm{~cm}^{3} / 60 \mathrm{mg}\right)$. The cartridge was washed with $2 \mathrm{~mL} 0.1 \mathrm{M} \mathrm{HCl}$ and $2 \mathrm{~mL} \mathrm{MeOH}$. The analytes were recovered with $2 \mathrm{~mL}$ ammonium hydroxide $(25 \%)$ and $\mathrm{MeOH}(1 / 19, v / v)$ and frozen at $-30{ }^{\circ} \mathrm{C}$ until further use. The samples were evaporated in a water bath at $40{ }^{\circ} \mathrm{C}$ with a constant nitrogen flow. The extracts were finally dissolved in $100 \mu \mathrm{L}$ of $\mathrm{MeOH}$ for further quantification.

\subsection{Chromatographic Separation}

The identification and quantification of HCA followed the methodology described by Oz et al. [9] using HPLC equipment (Agilent Technologies, Santa Clara, CA, USA) with a diode array detector (Agilent, 1220 infinity DAD, LC, USA). The separation was carried out on a reversed phase analytical column, TSK-GEL ODS-80TM $5 \mu \mathrm{m}(4.6 \times 25 \mathrm{~cm})$ from Tosoh Bioscience (Labkemi, Lund, Sweden) protected by a guard column (LC-18-DB, Sweden) at $35{ }^{\circ} \mathrm{C}$. The separation was achieved with a mobile phase of methanol/acetonitrile/acetic acid/water (8:14:2:76, v/v/v/v) pH 5 (adjusted with 25\% ammonium hydroxide) as solvent $\mathrm{A}$ and acetonitrile as solvent $\mathrm{B}$. The flow rate was $0.7 \mathrm{~mL} / \mathrm{min}$. A gradient program (0-10 min, $0 \% \mathrm{~B}, 11-20 \mathrm{~min}, 0 \%-23 \% \mathrm{~B}, 21-30 \mathrm{~min}, 23 \% \mathrm{~B}, 31-45 \mathrm{~min}, 0 \% \mathrm{~B}$ ) was used. The injection volume of the final extract was $10 \mu \mathrm{L}$.

The identification of HCA was carried out comparing the retention time recorded by each standard and samples enriched with HCA standards at $264 \mathrm{~nm}$. The recovery rate of HCA in the samples was determined by adding standards before extraction. The concentration of the HCA in the samples was calculated using a standard curve considering the indications of Haskaraca et al. [10]. Quantitative determination was performed using an external calibration curve method. A linear regression of amine concentration (versus the peak area of the amines) was performed. The regression coefficients $\left(R^{2}\right)$ for the amines were: 0.9974, 0.9958, 0.9583, 0.9852, 0.9940, and 0.9779 for IQx, IQ, MeIQx, MeIQ, 4,8DiMeIQx, and PhIP, respectively.

\subsection{Statistical Analysis}

The response surface methodology (RSM) was used to develop the prediction models. The analysis of variance (ANOVA), the determination coefficient $\left(\mathrm{R}^{2}\right)$, and the lack of fit of the models were determined using Design Expert (V.7.6.1, Stat-Ease, Inc., Minneapolis, MN, USA). The mathematical model corresponding to CCD is:

$$
\mathrm{y}=\beta_{0}+\sum_{i=1}^{3} \beta_{i} X_{1}+\sum_{i=1}^{3} \beta_{i i} X_{i}^{2}+\sum_{i<j} \beta_{i j} X_{i} X_{j}+\varepsilon
$$

where y are the response variables (formation of heterocyclic amines), $\beta_{0}, \beta_{\mathrm{i}}, \beta_{\mathrm{ii}}$, and $\beta_{\mathrm{ij}}$ are the coefficient of the intercept, liner, quadratic, and interaction, respectively, and $X_{i-j}$ are independent variables (roselle extract, potato peel flour, and fat).

The numerical optimization technique of the software Design-Expert was used for the simultaneous optimization of the multiple response. The formation of heterocyclic amines (IQ, IQx, MeIQ, MeIQx, 4,8-DiMeIQx, and PhIP) was kept as a minimum target.

\section{Results and Discussion}

Values for totals HCA are shown in Table 1. Individual HCA contents ranged from 0 to $18.09 \mathrm{ng}$ IQx, 0.20 to $11.66 \mathrm{ng} \mathrm{IQ}, 0.29$ to $3.93 \mathrm{ng}$ MeIQx, 0.19 to $11.51 \mathrm{ng}$ MeIQ, 0.65 to $1.72 \mathrm{ng}$ 4,8-DiMeIQx, and 1.87 to $14.7 \mathrm{ng}$ PhIP per gram. Table 2 shows the means and regression equations obtained for the prediction of the heterocyclic amines formed during cooking of beef patties prepared with roselle extract, potato peel flour, and fat. A greater effect by the incorporation of roselle extract was observed in the decrease of the studied HCA. Linear equations $(p<0.05)$ were adjusted in the formation of IQ, 4,8-DiMeIQx, and 
PhIP obtaining only a significant decrease by the roselle extract. While the polynominal equations of IQx, MeIQx, and MeIQ as well as quadratic equations were obtained, observing a negative linear and positive quadratic effect by the roselle extract. A positive quadratic effect was found from the effect of the incorporation of potato peel flour, allowing the formation of MeIQx and total HCA. On the other hand, a quadratic positive effect of the added fat was observed in the formation of MeIQx.

The observed values of HCA in our beef patties are similar to some reported studies, where the effect of other vegetable extracts were evaluated [10,11]. However, it is important to highlight that the quantity of amines formed depends on the type of meat, time, and type of cooking $[12,13]$. A significant effect of the decrease of the HCAs was found by the effect of the roselle extract. This is because the roselle is a flower rich in phenolic compounds that confers an antioxidant capacity [14]. It has been shown that antioxidants decrease the HCA formation due to antioxidants stabilizing the pirizine and/or pyrazyl radicals avoiding the union with creatinine. This way the aminoimidazole part of the amine is not formed [15]. On the other hand, the potato peel flour incorporation had a contrary effect to what was expected, increasing the MeIQx content. Potato peel flour contains a carbohydrate quantity of 275 to 1014 equivalents of glucose per gram of peel [16]. This causes an increase in glucose, which is a precursor of the HCA formation. This is causing a greater amount of MeIQx. The fat content in treatments does not have a significative impact on the HCA formation except in the MeIQx, where a positive quadratic effect was found. Fat was previously reported to promote the formation of heterocyclic amines [17]. However, it has been reported that a greater amount of HCA is formed in lean meat [18]. This is because, in meat with higher fat, there are fewer precursors, such as amino acids and glucose for the HCA formation. Some authors report that fattier meats have greater heat transmission, so foods cook faster, thus, allowing less amines formation $[19,20]$. On the other hand, optimization of the ingredients used for formulation of beef patties in this study was performed as described in the Materials and Methods section. The desirability function approach is one of the most utilized methods for the multiple response process optimization. In this study, the optimal formulation of beef patties that minimize HCA formation was estimated using the numerical optimization tool of the Design Expert software. According to the maximum desirability of multiple responses (0.92), the optimal formulation included $0.80 \%$ of roselle extract, $0.85 \%$ of potato peel, and $7.54 \%$ of beef fat. Predicted values for the HCA formation of the optimal formulation were: $0 \mathrm{ng}$ IQx, 1.89 ng IQ, 0.29 ng MeIQx, 0.04 ng MeIQ, 0.85 ng 4,8-DiMeIQx, and 4.01 ng PhIP per gram of the sample.

Table 2. Analysis of variance of the regression models and regression coefficients for heterocyclic amines formed during cooking of beef patties prepared with roselle extract, potato peel flour, and fat.

\begin{tabular}{ccccccc}
\hline Response & Model & Means \pm SD & $\mathbf{R}^{2} \mathbf{a}$ & Fvalue & Prob $>\mathbf{F}$ & Polynomial Equation $^{\mathbf{b}}$ \\
\hline IQx & Quadratic & $4.40 \pm 3.65$ & 0.75 & 3.22 & 0.041 & $\begin{array}{c}0.13-3.74 \mathrm{~A}^{*}+0.17 \mathrm{~B}-0.38 \mathrm{C}-1.23 \mathrm{AB}- \\
0.24 \mathrm{AC}+1.26 \mathrm{BC}+1.62 \mathrm{~A}^{2 *}+2.74 \mathrm{~B}^{2}+1.89 \mathrm{C}^{2}\end{array}$ \\
\hline IQ & Linear & $4.32 \pm 1.57$ & 0.69 & 11.61 & $<0.001$ & $4.32-2.19 \mathrm{~A}^{*}+0.90 \mathrm{~B}-0.85 \mathrm{C}$ \\
\hline MeIQx & Quadratic & $1.74 \pm 0.94$ & 0.73 & 3.07 & 0.048 & $\begin{array}{c}0.56-0.61 \mathrm{~A}^{*}-0.28 \mathrm{~B}-0.45 \mathrm{C}+0.37 \mathrm{AB}+ \\
0.13 \mathrm{AC}+0.25 \mathrm{BC}+0.32 \mathrm{~A}^{2}+0.73 \mathrm{~B}^{2 *}+0.69 \mathrm{C}^{2} \\
*\end{array}$ \\
\hline MeIQ & Quadratic & $2.90 \pm 1.79$ & 0.84 & 5.63 & 0.006 & $\begin{array}{c}1.07-2.65 \mathrm{~A}^{*}+0.64 \mathrm{~B}-0.03 \mathrm{C}-1.34 \mathrm{AB}+ \\
0.09 \mathrm{AC}-1.09 \mathrm{BC}+1.37 \mathrm{~A}^{2 *}+0.98 \mathrm{~B}^{2}+0.34 \mathrm{C}^{2}\end{array}$ \\
\hline DiMeIQ & Linear & $1.14 \pm 0.23$ & 0.66 & 10.08 & $<0.001$ & $1.14-0.28 \mathrm{~A}^{*}+0.03 \mathrm{~B}+0.18 \mathrm{C}^{*}$ \\
\hline PhIP & Linear & $6.19 \pm 3.67$ & 0.28 & 2.08 & 0.143 & $6.19-2.20 \mathrm{~A} * 0.14 \mathrm{~B}-1.14 \mathrm{C}$ \\
\hline
\end{tabular}




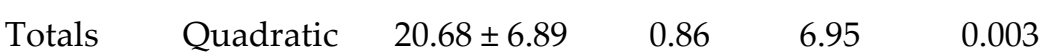

$10.64-11.67 \mathrm{~A}^{*}+1.32 \mathrm{~B}-2.68 \mathrm{C}-2.51 \mathrm{AB}-$
$1.14 \mathrm{AC}-1.08 \mathrm{BC}+4.50 \mathrm{~A}^{2 *}+6.31 \mathrm{~B}^{2 *}+$
$3.90 \mathrm{C}^{2}$

a $0<\mathrm{R}^{2}<1$, close to 1 means more significant. ${ }^{\mathrm{b}}$ A: roselle extract. B: potato peel flour. $\mathrm{C}$ : fat. ${ }^{*} p<$ 0.05. $\mathrm{SD}=$ standard deviation.

\section{Conclusions}

The incorporation of roselle extract decreases HCA formation in beef patties, while the potato peel flour has a contrary effect. The incorporation of fat has no significate effect in the majority of the HCA, only in the MeIQx. Roselle extract and potato peel are foods that can be used as ingredients to minimize the formation of HCA in beef patties.

Author Contributions: Conceptualization, formal analysis and writing-original draft preparation, M.V.-M. and J.P.C. Methodology and investigation, A.J.P.-B. Writing - review and editing, G.G.-A. and M.V.-M. All authors have read and agreed to the published version of the manuscript.

Funding: This research received no external funding.

Institutional Review Board Statement: Not applicable.

Informed Consent Statement: Not applicable.

Data Availability Statement: The data presented in this study are available on request from the corresponding author.

Acknowledgments: A. Pérez-Báez thanks CONACYT (National Council of Science and Technology) for the doctoral fellowship.

Conflicts of Interest: The authors declare no conflict of interest.

\section{References}

1. Trichopoulou, A.; Lagiou, P.; Kuper, H.; Trichopoulos, D. Cancer and Mediterranean dietary traditions. Cancer Epidemiol. Biomark. Prev. 2000, 9, 869-873.

2. Muller, A.E.; Skurtveit, S.; Clausen, T. Many correlates of poor quality of life among substance users entering treatment are not addiction-specific. Health Qual. Life Outcomes 2016, 14, 39.

3. Norat, T.; Riboli, E. Meat consumption and colorectal cancer: A review of epidemiologic evidence. Nut. Rev. 2001, 59, 37-47.

4. Vitaglione, P.; Fogliano, V. Use of antioxidants to minimize the human health risk associated to mutagenic/carcinogenic heterocyclic amines in food. J. Chromatogr. B 2004, 802, 189-199.

5. Barbosa-Pereira, L.; Aurrekoetxea, G.P.; Angulo, I.; Paseiro-Losada, P.; Cruz, J.M. Development of new active packaging films coated with natural phenolic compounds to improve the oxidative stability of beef. Meat Sci. 2014, 97, $249-254$.

6. Jeddou, K.B.; Chaari, F.; Maktouf, S.; Nouri-Ellouz, O.; Helbert, C.B.; Ghorbel, R.E. Structural, functional, and antioxidant properties of water-soluble polysaccharides from potatoes peels. Food Chem. 2016, 205, 97-105.

7. Gray, J.; Gomaa, E.; Buckley, D. Oxidative quality and shelf life of meats. Meat Sci. 1996, 43, 111-123.

8. Messner, C.; Murkovic, M. Evaluation of a new model system for studying the formation of heterocyclic amines. J. Chromatogr. B 2004, 802, 19-26.

9. Oz, F.; Kızıl, M. Determination of heterocyclic aromatic amines in cooked commercial frozen meat products by ultrafast liquid chromatography. Food Anal. Methods 2013, 6, 1370-1378.

10. Haskaraca, G.; Demirok, E.; Kolsarıcı, N.; Öz, F.; Özsaraç, N. Effect of green tea extract and microwave pre-cooking on the formation of heterocyclic aromatic amines in fried chicken meat products. Food Res. Int. 2014, 63, 373-381.

11. Lu, F.; Kuhnle, G.K.; Cheng, Q. Vegetable oil as fat replacer inhibits formation of heterocyclic amines and polycyclic aromatic hydrocarbons in reduced fat pork patties. Food Control. 2017, 81, 113-125.

12. Johansson, M.A.; Fay, L.B.; Gross, G.A.; Olsson, K.; Jägerstad, M. Influence of amino acids on the formation of mutagenic/carcinogenic heterocydic amines in a model system. Carcinogenesis 1995, 16, 2553-2560.

13. ur Rahman, U.; Sahar, A.; Khan, M.I.; Nadeem, M. Production of heterocyclic aromatic amines in meat: Chemistry, health risks and inhibition. A review. LWT Food Sci. Technol. 2014, 59, 229-233.

14. Pérez-Báez, A.J.; Camou, J.P.; Valenzuela-Melendres, M.; González-Aguilar, G.; Viuda-Martos, M.; Sebranek, J.G.; TortoledoOrtiz, O. Effects and interactions of roselle (Hibiscus sabdariffa L.), potato peel flour, and beef fat on quality characteristics of beef patties studied by response surface methodology. J. Food Process. Preserv. 2020, 44, e14659.

15. Murkovic, M.; Steinberger, D.; Pfannhauser, W. Antioxidant spices reduce the formation of heterocyclic amines in fried meat. Z. Lebensm. Unters. Forsch. 1998, 207, 477-480. 
16. Alvarez, V.H.; Cahyadi, J.; Xu, D.; Saldaña, M.D. Optimization of phytochemicals production from potato peel using subcritical water: Experimental and dynamic modeling. J. Supercrit. Fluids 2014, 90, 8-17.

17. Robbana-Barnat, S.; Rabache, M.; Rialland, E.; Fradin, J. Heterocyclic amines: Occurrence and prevention in cooked food. Environ. Health Persp. 1996, 104, 280-288.

18. Oz, F.; Kotan, G. Effects of different cooking methods and fat levels on the formation of heterocyclic aromatic amines in various fishes. Food Control 2016, 67, 216-224.

19. Abdulkarim, B.G.; Smith, J.S. Heterocyclic amines in fresh and processed meat products. J. Agric. Food Chem. 1998, 46, 46804687.

20. Szterk, A.; Roszko, M.; Małek, K.; Kurek, M.; Zbieć, M.; Waszkiewicz-Robak, B. Profiles and concentrations of heterocyclic aromatic amines formed in beef during various heat treatments depend on the time of ripening and muscle type. Meat Sci. 2012, 92, 587-595. 